Archives of Agriculture and Environmental Science

\title{
Effect of different phosphorus levels on four cowpea (Vigna unguiculata Walp L.) varieties for grain and fodder yield in Upper East Region of Ghana
}

\section{Boakye Boateng Augustine ${ }^{*}$ and Wilson Godfre}

Crop and Soil Science Department, Kwame Nkrumah University of Science and Technology, PMB Knust, Kumasi - Ashanti, GHANA *Corresponding author's E-mail: aboakyeboateng@gmail.com

\section{ARTICLE HISTORY}

Received: 24 May 2019

Revised received: 01 June 2019

Accepted: 03 June 2019

\section{Keywords}

Cowpea (Vigna unguiculata)

Fodder yield

Grain yield

Phosphorus doses

Soil characteristics

\begin{abstract}
A field experiment was conducted to examine the effect of cowpea varieties and different phosphorus levels on grain and fodder yield. Four cowpea varieties i.e. Asetenapa, Asomdwe, Hewale and Videza with four different phosphorus levels of single superphosphate (SSP) were used in the experiment. The experimental design was $4 \times 4$ factorial experiment laid in randomized complete block with four replicates. The results showed that cowpea varieties and phosphorus levels significantly influenced number of nodules per plant, pod length, number of pods per plant, fodder yield and grain yield. Phosphorus levels had no significant effect on stem girth, plant height and 100 seed weight. Asomdwe recorded the highest grain yield of $1229 \mathrm{kgha}^{-1}$ while Videza and Asetenapa produced the highest fodder yield of $957 \mathrm{kgha}$ ${ }^{-1}$. Interactive effect between Videza and $30 \mathrm{kgha}^{-1}$ of SSP produced the highest fodder yield while Asomdwe and $60 \mathrm{kgha}^{-1}$ of SSP was the treatment combination that produced the highest grain yield. Cowpea varieties and different phosphorus levels had effect on grain and fodder yield. Asomdwe would be recommended for commercial grain production because of the high grain yielding potential as observed in the study Asetenapa and Videza for fodder production to feed livestock.
\end{abstract}

(C)2019 Agriculture and Environmental Science Academy

Citation of this article: Augustine, B.B. and Godfre, W. (2019). Effect of different phosphorus levels on four cowpea (Vigna unguiculata Walp L.) varieties for grain and fodder yield in Upper East Region of Ghana. Archives of Agriculture and Environmental Science, 4(2): 242-248, https://dx.doi.org/10.26832/24566632.2019.0402018

\section{INTRODUCTION}

Cowpea (Vigna unguiculata Walp (L.) is an essential component of the cropping systems in the drier regions of the tropics and of vital importance to the livelihood of millions of people in West and Central Africa. It provides nutritious grain and an inexpensive source of protein for both rural and urban consumers (Anyango et al., 2011). Cowpea is consumed in many forms with young fresh leaves, immature green pods and green seeds used as vegetables; dry seeds used in various food preparations including over 50 different dishes known (Quaye et al., 2009); Boukar et al. (2011). The beans are nutritious and provide complementary proteins to cereals. The seeds of cowpea comprise (20 - 24\%) protein, $63.3 \%$ carbohydrates and $1.9 \%$ fat (Davis et al., 1991). Globally, it is grown on about 14.5 million hectares producing over 6.5 million metric tons of grain (Fatokun et al., 2012). Africa alone accounts for about $83 \%$ of the world production, with Nigeria being the world's largest producer (45.76\%), followed by Niger (15\%) (Fatokun et al., 2012). Fodder from cowpea is also highly valued for livestock. It can be grown as a relay inter-crop with cereals or other crops in mid, if maturing varieties were used (Elawad, 2000).

Farmers in legume production usually receive little mineral phosphorus fertilizer from the natural available soil phosphorus and other nutrients for nitrogen fixation and growth, and this result to low yields (Singh et al, 2011 and Nkaa et al, 2014). Inadequate supply of phosphorus may result in nitrogen deficiency when legumes depend on symbiotic nitrogen (Tairo and Ndakidemi, 2013) as a result of poor $\mathrm{N}_{2}$ fixation. Phosphorus (P) deficiency is the most frequent nutrient stress for growth and development of grain legumes including cowpea (Kamara et al., 2008). Soil phosphorus is in the form of poorly soluble mineral phosphates which is not readily available to plants (Marschner, 2012). 
Phosphorus has been reported to enhance the formation of lateral, fibrous and adventitious roots, which play an important role in $\mathrm{N}_{2}$ fixation, nutrient and water uptake (Rahman et al., 2008; Niu et al., 2012). It is one of the most important soil major nutrients for crop production especially legumes, it is rated the second to nitrogen in terms of its importance to crop performance (Halder and Panda, 2014). Phosphorus (P) is very significant element to enhance the cowpea biomass and crop yield because it stimulates growth, initiate nodulation as well as influence the efficiency of rhizobium-Legume symbiosis (Haruna and Usman, 2013). Therefore the requirement of $P$ for cowpea is quite higher than nitrogen in the form of single super phosphate or SUPA (Nkaa et al., 2014). The objective of the study was to determine the effect of different Phosphorus fertilizer level on grain and fodder yield of four cowpea varieties and effect of the four cowpea varieties on grain and fodder yield.

\section{MATERIALS AND METHODS}

\section{About the experimental sites}

The study was established on $15^{\text {th }}$ July, 2017 in Bonia in the Kessena - Nankana Municipality in the Upper East Region of Ghana, located on latitude $10.87^{\circ} \mathrm{N}$ and longitude $1.13^{\circ}$ west at $194 \mathrm{~m}$ above sea level. The climate is warm, semi-arid with mono-modal with the average annual rainfall amount of about $1000 \mathrm{~mm}$ which falls mostly between May and September. This is then followed by seven months of dry season, which is characterized by the dry harmattan winds with high risk of uncontrolled bushfires resulting in the loss of vegetative cover of the vertisol soil.

\section{Experimental design and treatment}

The experimental sites were ploughed and ridged and sprayed with herbicides (roundup and stomp) having active ingredients glyphosate and pendimethalin respectively. The experimental was laid out in factorial design arranged in randomized complete block design with four replications. The replicates were made up of 16 plots each measuring $4 \mathrm{~m} \times 2.4 \mathrm{~m}$ with 4 rows per plot, each row had a length of $4 \mathrm{~m}$, plot width of $2.4 \mathrm{~m}$, one meter between plots, $60 \mathrm{~cm}$ spacing between rows and 20 $\mathrm{cm}$ within rows with one meter between plots. The treatments used for the experiment were four single superphosphate fertilizer levels in $\mathrm{kgha}^{-1}$; 0, 30, 60, 90 and four cowpea varieties; Asetenapa, Asomdwe, Hewale and Videza. Three seeds were sown per hill and later thinned to two plants per hill two weeks after sowing; refilling was done two weeks after planting and weeding done by hoeing and hand pulling three weeks and five weeks after planting. Single Superphosphate (SSP) fertilizer at the rates indicated in the treatment was uniformly applied on the plots three days before planting. Composite soil samples at a depth of $0-15 \mathrm{~cm}$ were taken diagonally across the field before planting and soil sample analyzed for $\mathrm{pH}$, organic matter, Organic carbon, total $\mathrm{N}$, available $\mathrm{P}$ and exchangeable $\mathrm{K}$. Harvesting was done on the two middle rows of each plot and data collected included growth parameters, yield and yield components.

\section{Growth parameters and yield measurements}

\section{Plant height}

Five plants in the two middle rows of each plot were randomly selected, identified with a tag and plant height taken at harvest of each experiment. Height measurement was done from the ground level to the last terminal leaf. The average of five plants was then calculated for the plant height.

\section{Stem girth}

Were also measured from five cowpea plants from each plot of each treatment using electronic venire calipers. The stem girth of each of the five cowpea plants were placed in the external jaws of the calipers and the reading that was displaced on the LCD display recorded, the average was taken as the stem girth for plot.

Number of nodules per plant and nodules dry weight

The number of nodules per plant was taken from the five selected and tagged plants within the two middle rows. The roots of the plant were thoroughly washed to expose the nodules and a sharp blade was used to cut through the nodules. Viable nodules were counted, that is nodules with pinkish coloration and had the ability to fix nitrogen were counted and the average taken as the number of nodules per plant.

\section{Pod length}

The pod length of five cowpea pod were taken from each plot and measured using a ruler and the average length of the five pods taken as pod length.

\section{Number of pods and grain yield}

Pod harvest from five cowpea plants were counted and the average taken as the number of pods per plant. The pods in the two middle rows of each treatment were harvested and thrashed the seeds weighed for grain yield of each treatment.

\section{0 seed weight}

100 seeds from cowpea plants in the middle rows of each plot of each treatment from respective net plots were weighed for 100 seeds weight.

\section{Fodder yield}

The fodder from each of the five plants from each treatment was sun dried from each net plot, bulked and weighed then extrapolated as the fodder yield for treatment.

\section{Statistical analysis}

The data collected were subjected to statistical analysis using Genstat discovery edition 12 (2012). The means of the various treatments were separated using the least significant difference (LSD) at $5 \%$ probability level. 


\section{RESULTS AND DISCUSSION}

\section{Characteristics of the experimental soil}

The soils were slightly acidic, loamy sand with low available $\mathrm{P}$, total $\mathrm{N}$, exchangeable potassium and very low organic matter (Table 1).

Plant height, stem girth and pod length

The effects of cowpea varieties and different phosphorus levels on plant height, stem girth and pod length have been shown in Table 2. The cowpea varieties and the different phosphorus levels had little or no influence on plant height and stem girth as observed in the study, however a significant varietal influence on pod length was observed with no effect of the different phosphorus levels on pod length. Asomdwe produced the highest plant height of $46.61 \mathrm{~cm}$ while Videza produced the lowest plant height of $45.44 \mathrm{~cm}$. The little or lack of significant difference between the cowpea varieties for plant height and stem girth could be attributed to the lack of varietal effect between the cowpea varieties for plant height. This observation in the study is contrary to Magani and Kuchinda (2009) who attributed differences in plant height to the genetic effect of individual varieties. Karikari et al. (2015), El Naim (2012) and Abduselam (2018) reported varietal differences among cowpea and sorghum (Sorghum bicolor L. Moench) for plant height.

$60 \mathrm{kgha}^{-1}$ of SSP produced the highest plant height of $46.14 \mathrm{~cm}$ even though it was not significantly different from $0 \mathrm{kgha}^{-1}$ which recorded the lowest plant height of $45.16 \mathrm{~cm}$. The lack of significant difference of phosphorus levels on plant height as witnessed in the study is contrary to Ayodele and Oso (2014) who reported significant increase of plant height of cowpea when P was applied with basal N+K. Halder and Panda (2014) also observed a significant effect of different phosphorus levels on plant height in a groundnut. Nkaa et al. (2014) also observed that plant height of cowpea and number of leaves per plant was significantly enhanced by phosphorus application. There was a lack of interactive effect between the cowpea varieties and the different phosphorus levels on plant height and stem girth.

Table 1. Soil characteristics of experimental site.

\begin{tabular}{ll}
\hline Soil parameter & Value \\
\hline Texture class & loamy sand \\
$\mathrm{pH}$ & 5.59 \\
Organic matter $(\mathrm{g} / \mathrm{kg})$ & 66 \\
Organic carbon $(\mathrm{g} / \mathrm{kg})$ & 3 \\
Total N $(\mathrm{g} / \mathrm{kg})$ & 114 \\
Available P $(\mathrm{mg} / \mathrm{kg})$ & 9.68 \\
Exchangeable K $(\mathrm{cmolc} / \mathrm{kg})$ & 0.14 \\
\hline
\end{tabular}

Table 2. Effect of cowpea variety and different phosphorus levels on plant height, stem girth and pod length.

\begin{tabular}{|c|c|c|c|}
\hline & Plant height (cm) & Stem girth (mm) & Pod length $(\mathrm{cm})$ \\
\hline \multicolumn{4}{|l|}{ Variety } \\
\hline $\mathrm{V}_{1}=$ Asetenapa & 46.46 & 39.31 & 8.91 \\
\hline $\mathrm{V}_{2}=$ Asomdwe & 46.61 & 38.49 & 10.83 \\
\hline $\mathrm{V}_{3}=$ Hewale & 46.14 & 38.46 & 9.64 \\
\hline $\mathrm{V}_{4}=$ Videza & 45.44 & 39.88 & 11.29 \\
\hline LSD (0.05) & NS & NS & 0.52 \\
\hline \multicolumn{4}{|l|}{ P levels (kg/ha) } \\
\hline$P_{1}=0$ & 45.16 & 38.52 & 10.39 \\
\hline$P_{2}=30$ & 46.01 & 38.75 & 10.28 \\
\hline$P_{3}=60$ & 46.14 & 40.35 & 10.11 \\
\hline$P_{4}=90$ & 45.44 & 38.50 & 9.99 \\
\hline LSD (0.05) & NS & NS & NS \\
\hline \multicolumn{4}{|l|}{ Variety $\times$ P levels } \\
\hline $\mathrm{V}_{1} \times \mathrm{P}_{1}$ & 46.65 & 38.85 & 9.2 \\
\hline $\mathrm{V}_{2} \times \mathrm{P}_{1}$ & 43.95 & 40.05 & 10.95 \\
\hline$V_{3} \times P_{1}$ & 45.9 & 35.75 & 9.9 \\
\hline $\mathrm{V}_{4} \times \mathrm{P}_{1}$ & 44.13 & 39.45 & 11.53 \\
\hline $\mathrm{V}_{1} \times \mathrm{P}_{2}$ & 47.18 & 40.35 & 8.7 \\
\hline $\mathrm{V}_{2} \times \mathrm{P}_{2}$ & 44.9 & 39.60 & 10.4 \\
\hline $\mathrm{V}_{3} \times \mathrm{P}_{2}$ & 45.78 & 37.35 & 9.85 \\
\hline $\mathrm{V}_{4} \times \mathrm{P}_{2}$ & 46.2 & 37.70 & 11.78 \\
\hline $\mathrm{V}_{1} \times \mathrm{P}_{3}$ & 45.5 & 38.90 & 8.85 \\
\hline $\mathrm{V}_{2} \times \mathrm{P}_{3}$ & 47.75 & 36.05 & 10.98 \\
\hline $\mathrm{V}_{3} \times \mathrm{P}_{3}$ & 45.73 & 44.50 & 9.5 \\
\hline $\mathrm{V}_{4} \times \mathrm{P}_{3}$ & 44.75 & 41.95 & 11.13 \\
\hline $\mathrm{V}_{1} \times \mathrm{P}_{4}$ & 46.5 & 39.15 & 8.9 \\
\hline $\mathrm{V}_{2} \times \mathrm{P}_{4}$ & 49.83 & 38.25 & 11.0 \\
\hline $\mathrm{V}_{3} \times \mathrm{P}_{4}$ & 47.18 & 36.20 & 9.33 \\
\hline $\mathrm{V}_{4} \times \mathrm{P}_{4}$ & 46.7 & 40.40 & 10.73 \\
\hline $\operatorname{LSD}(0.05)$ & NS & 5.64 & 1.04 \\
\hline C.V (\%) & 1.7 & 10.2 & 3.0 \\
\hline
\end{tabular}


Table 3. Effects of cowpea varieties and different phosphorus levels on nodules per plant, nodules dry weight and pods per plant.

\begin{tabular}{|c|c|c|c|}
\hline & Nodules per plant & Nodules dry weight & Pods per plant \\
\hline \multicolumn{4}{|l|}{ Variety } \\
\hline $\mathrm{V}_{1}=$ Asetenapa & 67.16 & 36.45 & 66.4 \\
\hline $\mathrm{V}_{2}=$ Asomdwe & 74.47 & 39.53 & 69.7 \\
\hline $\mathrm{V}_{3}=$ Hewale & 76.59 & 35.85 & 52.3 \\
\hline $\mathrm{V}_{4}=$ Videza & 76.93 & 40.81 & 60.0 \\
\hline LSD (0.05) & 7.41 & 2.68 & 5.94 \\
\hline \multicolumn{4}{|l|}{ P levels (kg/ha) } \\
\hline$P_{1}=0$ & 76.89 & 36.7 & 54.64 \\
\hline$P_{2}=30$ & 86.23 & 36.58 & 60.96 \\
\hline$P_{3}=60$ & 75.71 & 39.23 & 65.61 \\
\hline$P_{4}=90$ & 56.33 & 40.14 & 67.23 \\
\hline LSD (0.05) & 7.41 & 2.68 & 5.94 \\
\hline \multicolumn{4}{|l|}{ Variety $\times$ P levels } \\
\hline$V_{1} \times P_{1}$ & 72.5 & 36.65 & 54.3 \\
\hline $\mathrm{V}_{2} \times \mathrm{P}_{1}$ & 78.0 & 38.29 & 59.8 \\
\hline $\mathrm{V}_{3} \times \mathrm{P}_{1}$ & 66.4 & 33.98 & 50.3 \\
\hline $\mathrm{V}_{4} \times \mathrm{P}_{1}$ & 51.8 & 38.88 & 54.3 \\
\hline $\mathrm{V}_{1} \times \mathrm{P}_{2}$ & 78.5 & 37.3 & 66.1 \\
\hline $\mathrm{V}_{2} \times \mathrm{P}_{2}$ & 83.0 & 35.85 & 70.2 \\
\hline $\mathrm{V}_{3} \times \mathrm{P}_{2}$ & 79.6 & 32.55 & 50.2 \\
\hline $\mathrm{V}_{4} \times \mathrm{P}_{2}$ & 56.8 & 40.63 & 57.4 \\
\hline$V_{1} \times P_{3}$ & 79.4 & 36.35 & 72.4 \\
\hline $\mathrm{V}_{2} \times \mathrm{P}_{3}$ & 91.3 & 41.13 & 73.3 \\
\hline $\mathrm{V}_{3} \times \mathrm{P}_{3}$ & 79 & 37.8 & 54.1 \\
\hline $\mathrm{V}_{4} \times \mathrm{P}_{3}$ & 58.7 & 41.63 & 62.7 \\
\hline $\mathrm{V}_{1} \times \mathrm{P}_{4}$ & 77.2 & 36.5 & 73.0 \\
\hline $\mathrm{V}_{2} \times \mathrm{P}_{4}$ & 92.6 & 42.85 & 75.7 \\
\hline$V_{3} \times P_{4}$ & 79.8 & 39.08 & 54.5 \\
\hline $\mathrm{V}_{4} \times \mathrm{P}_{4}$ & 58.1 & 42.13 & 65.8 \\
\hline LSD (0.05) & 14.82 & 5.36 & 11.87 \\
\hline C.V (\%) & 4.5 & 1.9 & 3.7 \\
\hline
\end{tabular}

Videza was the cowpea variety that produced the longest pod length and was statistically different from Asetenapa, the variety with the shortest pod length. The varietal differences observed between the cowpea for pod length in the study could be attributed to genotypic variation between varieties used for the study. This observation is in agreement with (Belay et al., 2017) who reported varietal difference for pod length in a study of agronomic performance evaluation of cowpea varieties. Also the lack or little effect of the different phosphorus levels on pod length as observed in the study is contrary to Karikari et al. (2015) who reported a significant effect of different phosphorus on the pod length of cowpea. Lakew (2019) also reported a positive influence of phosphorus levels on pod length in his study growth and yield of wheat (Triticum aestivum L.) cultivars as influenced by rates of phosphorus. A significant interactive effect between cowpea varieties and phosphorus levels were observed for pod length. This shows that with Videza and $30 \mathrm{kgha}$ ${ }^{-1}$ phosphorus interaction produced the highest pod length with a mean 11.77 while Asetenapa and $30 \mathrm{kgha}^{-1}$ phosphorus interaction produced least pod length with a mean of 8.7.

Nodules per plant, nodules dry weight and pods per plant The effect of cowpea varieties and different phosphorus levels on number of nodules per plant, nodules dry weight and number of pods per plant are shown in Table 3. Varietal differences were observed in the number of nodules per plant, nodules dry weight and number of pods per plant. Asomdwe produced the highest nodule per plant from the results with a mean 86.2 compared with Videza which produced the least nodules per plant with a mean of 56.3. The varietal difference observed between the cowpea varieties used in the study could be attributed to genetic difference in the varieties interacting with the native rhizobia in forming effective and viable nodules. This finding agrees with Ayodele and Oso (2014) and Karikari et al. (2015) who reported varietal difference in nodules per plant in cowpea. The effect of the phosphorus levels on number of nodules per plant was statistically significant between the different phosphorus levels for number of nodules per plant. $90 \mathrm{kgha}^{-1}$ of phosphorus produced the highest nodules per plant with a mean of 76.93 while $0 \mathrm{kgha}^{-1}$ produced the lowest nodules per plant with a mean of 67.16. The results of this study are in agreement with (Agboola and Obigbesan, 1977) who indicated the effect of phosphorus on the number of nodules per plant. The finding also is in support of Rahman et al. (2008) and Niu et al. (2012) that phosphorus enhances the formation of lateral, fibrous and adventitious roots, which play an important role in nodule formation, $\mathrm{N}_{2}$ fixation, and nutrient and water uptake. A significant interactive effect between the varieties and the different phosphorus levels on nodules per plant as was observed from the studies. Interaction between Asomdwe and $90 \mathrm{kgha}^{-1}$ phosphorus produced the highest nodules per plant (92.6) while Videza and 0 $\mathrm{kgha}^{-1}$ interaction produced the least nodules per plant (51.8). 
Videza was the variety with the highest nodules dry weight with a mean of $40.81 \mathrm{~g}$ while Asetenapa produced the lowest nodules dry weight (36.45g). Phosphorus levels also had significant influence on nodules dry weight. $90 \mathrm{kgha}^{-1}$ phosphorus produced the highest nodules dry weight $(40.14 \mathrm{~g})$ while $30 \mathrm{kgha}^{-1}$ phosphorus produced the least nodule dry weight $(36.58 \mathrm{~g})$. The finding of this study is in conformity with (Nkaa et al., 2014) who reported that increasing phosphorus levels increase number and size of nodules.

Asomdwe produce the most number of pods per plant (69.7) while Hewale was the variety with least number of pods per plant (52.3). The difference in the number of pods per plant as observed between the varieties in the study may be as a result of genetic difference in partitioning photosynthesis into pods development. This finding agrees with Masenya (2016), who recorded significant varietal effect on number of pods per plant in evaluation of introduced cowpea lines. The finding is also collaborated by works of Shambharkar et al. (2006); Onat et al. (2016); Dapaah et al. (2014) and Sharma et al. (2013) who reported varietal effect for number of pods per plant in groundnut. A significant influence between $90 \mathrm{kgha}^{-1}$ of phosphorus $30 \mathrm{kgha}^{-1}$ and $0 \mathrm{kgha}^{-1}$ were observed for number of pods per plant. $90 \mathrm{kgha}^{-1}$ phosphorus levels produced the highest number of pods per plant (67.2) with Okgha ${ }^{-1}$ producing the lowest number of pods per plant (54.6). The significant difference in phosphorus levels on number of pods per plant as observed in the study is collaborated by Owolade et al. (2006) and Olaleye et al. (2011).

A significant interactive effect was also witnessed between the cowpea varieties and the different phosphorus levels for nodules dry weight and number of pods per plant. The interaction between Asomdwe and $90 \mathrm{kgha}^{-1}$ phosphorus levels produced the largest number of pods per plant (75.68) while as the interaction of Hewale and $30 \mathrm{kgha}^{-1}$ phosphorus levels produced smallest number of pods per plant (50.18).

100 seed weight, fodder yield and grain yield

The effects of varietal difference and different phosphorus levels on 100 seed weight, fodder and grain yield as presented in Table 4. A lack of significant different was observed between the cowpea varieties and the different phosphorus levels on 100 seed weight. Videza produced the highest 100 seed weight (59.42g) while Asomdwe produced the least 100 seed weight (58.24g). The absence of significant varietal and phosphorus levels differences in the study is contrary to (Henshaw, 2008) who observed significant varietal variations in 100 seed weights of cowpea cultivars. Shahid et al. (2009) reported significant influence of phosphorus levels and inoculation on 1000 seed weight of soybean which was contrary to what was observed in the study. Singh et al. (2011) also reported a significant effect of phosphorus levels on 100 seed weight of cowpea varieties in the Sudan Savanna of Nigeria.

There was a significant varietal variation between the cowpea varieties for fodder yield. Videza produced the highest fodder yield $\left(957 \mathrm{kgha}^{-1}\right)$ while Asomdwe produced the lowest fodder yield $\left(737.6 \mathrm{kgha}^{-1}\right)$. The difference in fodder yield between the varieties as observed in the study could be attributed genetic difference between the varieties. This observation consent to (Singh and Tarawali, 1997) who reveals significant differences among cowpea varieties for both grain and fodder yields of promising medium-maturing cowpea varieties. Singh et al. (2002) also reported significant fodder yield between selected breeding lines under intercropping and sole cropping averaged over two crosses. Also, (Relwani et al., 1970) reported significant difference between cowpea varieties for fodder yield in a study varietal trial on cowpea (Vigna sinensis) for fodder production.

A significant influence of phosphorus levels on fodder yield were observed in the study as shown in Table 4. There was as increase in the fodder yield as the phosphorus levels increase. $90 \mathrm{kgha}^{-1}$ produced the highest fodder yield $\left(915.4 \mathrm{kgha}^{-1}\right)$ while $0 \mathrm{kgha}^{-1}$ produced the least fodder yield $\left(784.5 \mathrm{kgha}^{-1}\right)$. The finding in this study is collaborated by (Sandhu et al., 1976) who in a study observed a significant increase in fodder quantity and quality when $25 \mathrm{~kg} \mathrm{P}_{2} \mathrm{O}_{5}$ were applied. Singh et al. (2011) also reported a significant cowpea stover yield when $60 \mathrm{~kg} \mathrm{P}_{2} \mathrm{O}_{5}$ were applied. A significant interactive effect between the cowpea varieties and phosphorus levels on fodder yield. Videza when applied with $30 \mathrm{kgha}^{-1}$ and $60 \mathrm{kgha}^{-1}$ of single superphosphate produced the highest fodder yield (1010.4kgha-1) while Asomdwe with $0 \mathrm{kgha}^{-1}$ of SSP produced the least fodder yield of $638 \mathrm{kgha}^{-1}$.

A significant varietal variation on grain yield was observed between the cowpea varieties used in the study as shown in Table 4. Asomdwe was the cowpea variety from the study that partitioned most of it's assimilates into grain production and produced the highest grain yield $\left(1229 \mathrm{kgha}^{-1}\right)$ while Videza produced the least grain yield $\left(1083 \mathrm{kgha}^{-1}\right)$. The varietal variation as observed in the study could be attributed to genotypic variation in phosphorus use efficiency among the cowpea varieties used in the study. This also shows that the different cowpea varieties inherently have different means of mobilizing phosphorus and other growth resources for grain production. This observation is in agreement with Singh and Tarawali (1997), Singh et al. (2002), Adjei-Nsiah et al. (2008) and Timko et al. (2007) who all reported significant varietal influence of grain yield.

A significant effect of the phosphorus levels on grain yield were also observed in the study. $90 \mathrm{kgha}^{-1}$ produced the highest grain yield $\left(1201 \mathrm{kgha}^{-1}\right)$ while $0 \mathrm{kgha}^{-1}$ produced the lowest grain yield of $\left(1138 \mathrm{kgha}^{-1}\right)$. The increase in grain yield by the $90 \mathrm{kgha}^{-1}$ might be as a result of the overall improvement in growth and yield attributing traits such as number of pods per plant, which also showed an increasing trend as a result of $P$ application. This finding in consistent with (Nkaa et al., 2014), Haruna and Usman (2013) and Ayodele and Oso (2014) who all reported a positive influence of phosphorus application on grain yield. The interaction effect on grain yield between cowpea varieties and the phosphorus levels also witnessed a significant difference. Asetenapa and $60 \mathrm{kgha}^{-1}$ interaction produced the highest grain yield with a mean of $1273 \mathrm{kgha}^{-1}$ while Videza and $90 \mathrm{kgha}^{-1}$ produced the least grain yield of $1069 \mathrm{kgha}^{-1}$. 
Table 4. Effect of cowpea variety and different phosphorus levels on 100 seed weight, fodder and grain yield.

\begin{tabular}{|c|c|c|c|}
\hline & 100 seed weight $(\mathrm{g})$ & Fodder yield (kg/ha) & Grain yield (kg/ha) \\
\hline \multicolumn{4}{|l|}{ Variety } \\
\hline $\mathrm{V}_{1}=$ Asetenapa & 56.69 & 957 & 1222 \\
\hline$V_{2}=$ Asomdwe & 58.24 & 737.6 & 1229 \\
\hline $\mathrm{V}_{3}=$ Hewale & 58.69 & 849.6 & 1144 \\
\hline $\mathrm{V}_{4}=$ Videza & 59.42 & 957 & 1083 \\
\hline $\operatorname{LSD}(0.05)$ & NS & 67.31 & 35.33 \\
\hline \multicolumn{4}{|l|}{ P levels (kg/ha) } \\
\hline$P_{1}=0$ & 58.78 & 784.5 & 1138 \\
\hline$P_{2}=30$ & 58.52 & 885.4 & 1158 \\
\hline$P_{3}=60$ & 60.15 & 888.7 & 1180 \\
\hline$P_{4}=90$ & 55.6 & 915.4 & 1201 \\
\hline $\operatorname{LSD}(0.05)$ & NS & 67.31 & 35.33 \\
\hline \multicolumn{4}{|l|}{ Variety $\times$ P levels } \\
\hline $\mathrm{V}_{1} \times \mathrm{P}_{1}$ & 65.6 & 843.8 & 1180 \\
\hline $\mathrm{V}_{2} \times \mathrm{P}_{1}$ & 63.0 & 638.0 & 1209 \\
\hline $\mathrm{V}_{3} \times \mathrm{P}_{1}$ & 52.2 & 760.4 & 1090 \\
\hline $\mathrm{V}_{4} \times \mathrm{P}_{1}$ & 54.3 & 895.8 & 1091 \\
\hline $\mathrm{V}_{1} \times \mathrm{P}_{2}$ & 57.7 & 929.7 & 1210 \\
\hline $\mathrm{V}_{2} \times \mathrm{P}_{2}$ & 56.3 & 724.0 & 1194 \\
\hline $\mathrm{V}_{3} \times \mathrm{P}_{2}$ & 58.2 & 877.6 & 1136 \\
\hline $\mathrm{V}_{4} \times \mathrm{P}_{2}$ & 61.9 & 1010.4 & 1098 \\
\hline $\mathrm{V}_{1} \times \mathrm{P}_{3}$ & 62.1 & 979.2 & 1273 \\
\hline $\mathrm{V}_{2} \times \mathrm{P}_{3}$ & 56.7 & 773.4 & 1264 \\
\hline$V_{3} \times P_{3}$ & 68.2 & 878.4 & 1172 \\
\hline $\mathrm{V}_{4} \times \mathrm{P}_{3}$ & 53.6 & 1010.4 & 1093 \\
\hline $\mathrm{V}_{1} \times \mathrm{P}_{4}$ & 52.3 & 966.1 & 1224 \\
\hline $\mathrm{V}_{2} \times \mathrm{P}_{4}$ & 58.8 & 815.1 & 1250 \\
\hline $\mathrm{V}_{3} \times \mathrm{P}_{4}$ & 54.4 & 862.0 & 1177 \\
\hline $\mathrm{V}_{4} \times \mathrm{P}_{4}$ & 56.9 & 911.5 & 1069 \\
\hline $\operatorname{LSD}(0.05)$ & 12.49 & 134.6 & 70.66 \\
\hline C.V (\%) & 4.6 & 1.0 & 1.2 \\
\hline
\end{tabular}

NS - not significant, LSD - Least Significant Difference, CV - coefficient of variation.

\section{Conclusion}

The findings of this study showed that cowpea varieties positively influenced pod length, dry nodules, nodules per plant, pods per plant fodder and grain yield but no influence on stem girth, plant height and 100 seed weight. Asomdwe was the cowpea variety that produced the highest grain yield with Asetenapa and Videza producing the highest fodder yield. The different phosphorus levels had a significant influence on pod length, nodules per plant; nodules dry weight, pod per plant, fodder yield and grain yield. $90 \mathrm{kgha}^{-1}$ of SSP produced the highest fodder and grain yield among the other phosphorus levels. The phosphorus levels had little or no significant influence on the stem girth, plant height and 100 seed weight. The interaction between Videza with $30 \mathrm{kgha}^{-1}$ and $60 \mathrm{kgha}$ produced the highest fodder yield and Asomdwe with $60 \mathrm{kgha}^{-1}$ produced the highest grain yield. It could therefore be recommended that for commercial production of fodder for livestock Videza and Asetenapa can be considered while Asomdwe could be considered for grain production.

Open Access: This is an open access article distributed under the terms of the Creative Commons Attribution 4.0 License, which permits unrestricted use, distribution, and reproduction in any medium, provided the original author(s) if the sources are credited.

\section{REFERENCES}

Abduselam, F., Tegene, S., Legese, Z. and Tadesse, F. (2018). Evaluation of early maturing Sorghum (Sorghum bicolor (L.) Moench) varieties, for yield and yield components in the lowlands of Eastern Hararghe. Asian Journal of Plant Science and Research, 8(1): 40-43.

Adjei-Nsiah, S., Kuyper, T. W., Leeuwis, C., Abekoe, M. K., Cobbinah, J., SakyiDawson, O. and Giller, K. E. (2008). Farmers' agronomic and social evaluation of productivity, yield and N2-fixation in different cowpea varieties and their subsequent residual $\mathrm{N}$ effects on a succeeding maize crop. Nutrient Cycling in Agroecosystems, 80: 199, https://doi.org/10.1007/s10705-007-9133-3

Agboola, A. and Obigbesan, G. (1977). Effect of different sources of levels of $P$ on the performance of $\mathrm{P}$ uptake of Ife-Brown variety of cowpea. Ghana Journal $\begin{array}{llll}\text { of } \quad \text { Agricultural } & \text { Science, }\end{array}$ https://eurekamag.com/research/000/865/000865745.php

Anyango, J.O., De Kock, H.L. and Taylor, J.R. (2011). Evaluation of the functional quality of cowpea-fortified traditional African sorghum foods using instrumental and descriptive sensory analysis. LWT-Food Science and Technology, 44: 2126-2133, https://doi.org/10.1016/j.lwt.2011.07.010

Ayodele, O. and Oso, A. (2014). Cowpea responses to phosphorus fertilizer application at Ado-Ekiti, South-West Nigeria. Journal of Applied Science and $\quad$ Agriculture, $4(2)$ 4 http://www.aensiweb.com/old/jasa/rjfh/2014/485-489.pdf

Belay, F., Gebreslasie, A. and Meresa, H. (2017). Agronomic performance evaluation of cowpea (Vigna unguiculata (L.) Walp] varieties in Abergelle District, Northern Ethiopia. Journal of Plant Breeding and Crop Science, 9(8): 139-143, https://doi.org/10.5897/JPBCS2017.0640

Boukar, O., Massawe, F., Muranaka, S., Franco, J., Maziya-Dixon, B., Singh, B. and Fatokun, C. (2011). Evaluation of cowpea germplasm lines for protein and mineral concentrations in grains. Plant Genetic Resources, 9(4): 515-522, https://doi.org/10.1017/S1479262111000815 
Dapaah, H. K., Mohammed, I. and Awuah, R.T. (2014). Growth yield performance of groundnuts (Arachis hypogaea L.) in response to plant density. International Journal of Plant and Soil Science, 3(9): 1069-1082, http://www.journalrepository.org/media/journals/IJPSS_24/2014/Jun/ Dapaah392014IJPSS9445_1.pdf

Davis, D., Oelke, E., Oplinger, E., Doll, J., Hanson, C. and Putnam, D. (1991). Field crops manure, University of Mipesota, St Paul, MN5510. University of Wisconsin-Madison W, 1, 53706.

El Naim, A., Jabereldah, A.A., Ahmed, S.E., Ismaeil, F.M. and Ibraim, E.A. (2012). Determination of suitable variety and plants per stand of cowpea (Vigna unguiculata L. Walp) in the sandy soil, Sudan. Advances in Life Science, 2 (1): 1-5, http://dx.doi.org/10.5923/j.als.20120201.01

Elawad, H. (2000). The performance of selected cowpea (Vigna unguiculata L. Walp). Varieties in the sandy rainfed areas of Kordofan. Agricultural Research Corporation, Elobied, Sudan.

Fatokun, C. A., Boukar, O. and Muranaka, S. (2012). Evaluation of cowpea (Vigna unguiculata (L.) Walp.) germplasm lines for tolerance to drought. Plant Genetic Resources, 10: 171-176, https://doi.org/10.1017/S1479262112000214

Halder, D. and Panda, R.K. (2014). Determination of appropriate sowing date and phosphorus fertilization strategy for peanut in Eastern India. African Journal of Agricultural Research, 9: 2475-2487, https://www.cabdirect.org/cabdirect/abstract/20143291730

Haruna, I. and Usman, A. (2013). Agronomic efficiency of cowpea varieties (Vigna unguiculata L. Walp) under varying phosphorus rates in Lafia, Nasarawa State, Nigeria. Asian Journal of Crop Science, 5(2): 209-215, https://doi.org/10.3923/ajcs.2013.209.215

Henshaw, F. (2008). Varietal differences in physical characteristics and proximate composition of cowpea (Vigna unguiculata). World Journal of Agricultural Sciences, 4: 302-306.

Kamara, A., Kwari, J., Ekeleme, F., Omoigui, L. and Abaidoo, R. (2008). Effect of phosphorus application and soybean cultivar on grain and dry matter yield of subsequent maize in the tropical savannas of north-eastern Nigeria. African Journal of Biotechnology, 7(15): 2593-2599, https://eurekamag.com/research/066/212/066212983.php

Karikari, B., Arkorful, E. and Addy, S. (2015). Growth, nodulation and yield response of cowpea to phosphorus fertilizer application in Ghana. Journal of Agronomy, 14: 234-240, https://dx.doi.org/10.3923/ja.2015.234.240

Lakew, A. (2019). Influence of $N$ and $P$ fertilizer rates on yield and yield components of bread wheat (Triticum aestivum L.) in Sekota District of Wag-Himira Zone, North Eastern Ethiopia. Archives of Agriculture and Environmental Science, 4(1): 8-18, https://dx.doi.org/10.26832/24566632.2019.0401

Magani, I. and Kuchinda, C. (2009). Effect of phosphorus fertilizer on growth, yield and crude protein content of cowpea (Vigna unguiculata [L.] Walp) in Nigeria. Journal of Applied Biosciences, 23: 1387-1393.

Marschner, P. (2012). Rhizosphere biology. Marschner's Mineral Nutrition of Higher Plants (Third Edition). Elsevier.

Masenya, T.A. (2016). Evaluation of introduced cowpea breeding lines in South Africa. Thesis (M.Sc. Agriculture (Agronomy)) - University of Limpopo, http://ulspace.ul.ac.za/handle/10386/1638

Niu, Y.F., Chai, R.S., Jin, G.L., Wang, H., Tang, C.X. and Zhang, Y.S. (2012). Responses of root architecture development to low phosphorus availability: a review. Annals of botany, 112: 391-408.

Nkaa, F., Nwokeocha, O. and Ihuoma, O. (2014). Effect of phosphorus fertilizer on growth and yield of cowpea (Vigna unguiculata). OSR Journal of Pharmacy and Biological Sciences, 9(5): 74-82, https://pdfs.semanticscholar.org/40d6/ a4f226b84caabdfddc05eb263d3322d7ea74.pdf
Olaleye, O., Olajire, F. and Nnenna, I. (2011). Phosphorus response efficiency in cowpea genotypes. Journal of Agricultural Science, 4(1): 81-90, https://dx.doi.org/10.5539/jas.v4n1p81

Onat, B., Bakal, H., Güllüoğlu, L. and Arıoğlu, H. (2016). The effects of row spacing and plant density on yield and yield components of peanut grown as a double crop in mediterranean environment in Turkey. Turkish Journal of Field Crops, 22(1): 71-80, http://www.field-crops.org/assets/pdf/product58ef4896efc30.pdf

Owolade, O., Adediran, J., Akande, M. and Alabi, B. (2006). Effects of application of phosphorus fertilizer on brown blotch disease of cowpea. African Journal of Biotechnology, 5: 343-347.

Quaye, W., Adofo, K., Madode, Y. and Abizari, A.R. (2009). Exploratory and multidisciplinary survey of the cowpea network in the Tolon-Kumbungu district of Ghana: A food sovereignty perspective. African Journal of Agricultural Research, 4: 311-320.

Rahman, M.M., Bhuiyan, M.M.H., Sutradhar, G.N.C. Rahman, M.M. and Paul, A.K. (2008). Effect of phosphorus, molybdenum and Rhizobium inoculation on growth and nodulation of mungbean. International Journal of Sustainable Crop Production, 3(6): 26-33, http://www.ggfjournals.com/assets/uploads/2633.pdf

Relwani, L., Kurar, C. and Bagga, R. (1970). Varietal trial on cowpea (Vigna sinensis) for fodder production. Indian Journal of Agronomy, 15: 166-168.

Sandhu, H., Puri, K. and Brar, S. (1976). Effect of sowing dates, harvesting intervals and phosphorus levels on the yield and quality of cowpeas fodder (India). Indian Journal of Agronomy, 21(1): 11-16.

Shahid, M.Q., Saleem, M. F., Khan, H.Z. and Anjum, S.A. (2009). Performance of soybean (Glycine max L.) under different phosphorus levels and inoculation. Pakistan Journal of Agricultural Sciences, 46(4): 237-241, https://www.cabdirect.org/cabdirect/abstract/20093349322

Shambharkar, D., Dharne, P., Bahale, T., Anjali, D., Surywanshi, R. and Jadhav, R. (2006). Assessment of integrated pest management modules in groundnut on farmers' fields. International Arachis Newsletter, 31-33, https://www.cabdirect.org/cabdirect/abstract/20073004573

Sharma, P., Sardana, V. and Kandhola, S. S. (2013). Effects of sowing dates and harvesting dates on germination and seedling vigor of groundnut (Arachis hypogaea) cultivars. Research Journal of Seed Science, 6(1): 1-15, https://dx.doi.org/10.3923/rjss.2013.1.15

Singh, A., Baoule, A., Ahmed, H., Dikko, A., Aliyu, U., Sokoto, M., Alhassan, J., Musa, M. and Haliru, B. (2011). Influence of phosphorus on the performance of cowpea (Vigna unguiculata (L) Walp.) varieties in the Sudan savanna of Nigeria. Agricultural $\quad$ Sciences, $2(3)$ : https://dx.doi.org/10.4236/as.2011.23042

Singh, B. and Tarawali, S. (1997). Cowpea and its improvement: key to sustainable mixed crop/livestock farming systems in West Africa. Crop Residues in Sustainable Mixed Crop/Livestock Farming Systems. CAB in Association with ICRISAT and ILRI, Wallingford, UK, 79-100.

Singh, B., Ehlers, J., Sharma, B. and Freire Filho, F. (2002). Recent progress in cowpea breeding. FATOKUN, CA; TARAWALI, SA; SINGH, BB; KORMAWA, PM, 22-40.

Tairo, E.V. and Ndakidemi, P.A. (2013). Possible benefits of rhizobial inoculation and phosphorus supplementation on nutrition, growth and economic sustainability in grain legumes. American Journal of Research Communication, 1 (12): 532-556, https://pdfs.semanticscholar.org/e305/ c242fee3c730acdfddd24debd154a438d2cc.pdf

Timko, M.P., Ehlers, J.D. and Roberts, P.A. (2007). Cowpea. Pulses, sugar and tuber crops. Springer, https://link.springer.com/book/10.1007/978-3-540-34516-9 